American Journal of Environmental Sciences 4 (4): 332-341, 2008

ISSN 1553-345X

(C) 2008 Science Publications

\title{
Evolution of Biochemical Parameters during Composting of Various Wastes Compost
}

\author{
${ }^{1}$ N.Saidi, ${ }^{2}$ M. Chérif, ${ }^{1}$ N. Jedidi, ${ }^{1}$ M. Mahrouk, ${ }^{3}$ M. Fumio, ${ }^{4}$ A. Boudabous and ${ }^{1}$ A. Hassen \\ ${ }^{1}$ Centre de Recherche et des Technologies des Eaux (CRTE) Laboratoire \\ Traitement et Recyclage B.P. 95 - 2050, Hammam Lif, Tunisie \\ ${ }^{2}$ Institut National de Recherches Agronomique de Tunis, Route Soukra, Tunis, Tunisie \\ ${ }^{3}$ JICA International Japanese cooperation agency Tunis \\ ${ }^{4}$ Faculté des Sciences de Tunis, Laboratoire de Microbiologie, \\ Campus universitaire, 1060 Tunis, Tunisie
}

\begin{abstract}
In Tunisia the most treatment waste is landfill (50\% of wastes were land filled) and only $5 \%$ are composted. And since our soil become more and more poor in organic matter, green waste can be a significant source of organic matter; in parallel we cited the domestic waste and dead posodonia collected from beaches. All these wastes coming from various origins can be exploited to produce stable compost able to correct the deficiency of soil. Exploiting waste could lead at different quality of mature compost. We are not interested in only the quality of the mature compost but we are interested in the time of the composting cycle. The goals of this study were to characterize the maturity and the sanitary quality of compost in relation with the feed stock source (green waste (C1), green waste mixed with Posidonia (C2) and municipal solid waste (C3). The results obtained showed that the duration of the cycle of composting depends on the nature of the substrate. The longest cycle (200 days) was observed with the feed stock source C3. The C/N ratios ranged between 22 and 27 at the beginning of the cycle of composting and decreased notably during time of composting. $\mathrm{NH}_{4}-\mathrm{N}$ decreased over the progress cycle and at the end of composting progress, all wastes presented a content of $\mathrm{NH}_{4}-\mathrm{N}$ not exceeding the maximal value recommended for mature compost (400 $\mathrm{mg} \mathrm{kg}^{-1}$ ). The $\mathrm{CO}_{2}$ released by $\mathrm{C} 1$ was of approximately $6000 \mathrm{mg} \mathrm{C}-\mathrm{CO}_{2} \mathrm{DM} \mathrm{kg}^{-1}$ at the start of the cycle and it reached at the end of the cycle of composting $2300 \mathrm{mg} \mathrm{C}-\mathrm{CO}_{2} \mathrm{DM} \mathrm{kg}^{-1}$. Nevertheless, the deshydrogenase activity (DHA) recorded was important during the thermophilous phase at the level of the three piles $\mathrm{C} 1, \mathrm{C} 2$ and $\mathrm{C} 3$, where it reached the respective values of 5.9; 6.2 and $4 \mathrm{TPFS} / \mathrm{TPF} / \mathrm{g}$ of DM. Maturity stage showed the values of $0.3 ; 0.8$ and $0.4 \mathrm{TPFS} / \mathrm{TPF} / \mathrm{g}$ of DM, respectively. Salmonella appeared only at the level of the piles C2 et C3 at the beginning of composting. After $40^{\text {th }}$ days composting these bacteria are not detected. Staphylocoques were not detected at the level of the two piles $\mathrm{C} 1$ and $\mathrm{C} 2$. The number of these bacteria was important in the compost $\mathrm{C} 3$, where it fluctuated between $10^{3}$ and $10^{5}$ bacteria $\mathrm{g}^{-1}$ of dry matter. Statistical analyses showed that the compost of municipal solid waste $\mathrm{C} 3$ presented a value of salinity $\left(6.8 \mathrm{~g} \mathrm{Kg}^{-1}\right.$ of $\mathrm{DM})$ higher than those obtained at the level of the other studied piles $2.6 \mathrm{~g} \mathrm{~kg}^{-1}$ of DM for C1; $4 \mathrm{~g} \mathrm{Kg}^{-1}$ of DM for C2). We also noted that the compost $\mathrm{C} 2$ was relatively rich in $\mathrm{P}(2.17 \% /$ of $\mathrm{DM})$ and $\mathrm{MgO}(2.62 \%$ of $\mathrm{DM})$ as compared with the two other studied piles which contain a percentage of $\mathrm{MgO}$ of 0.73 in $\mathrm{C} 1$ pile and 0.8 in $\mathrm{C} 3$ pile. Although important heavy metals contents determined in the three studied composts were lower than the levels indicated by the standards of the European Union.
\end{abstract}

Key words: Vegetable residues, posidonia oceanica, municipal solid waste, compost, staphylococcus, salmonellas

\section{INTRODUCTION}

Overexploitation and abusive use of chemical fertilisers led to soils poorer in humus content. Composting can not only transform waste by reducing its harmful effect but also corrects when added to soil, the deficit in organic matter. The nature of the raw material used during composting has a direct effect on the quality of the final product. There is a significant

Corresponding Author: N. Saidi, Centre de Recherche et des Technologies des Eaux (CRTE) Laboratoire Traitement et Recyclage, B.P. 95-2050, Hammam Lif, Tunisie 
need for the amendment of soils by compost. The quality of the amendment may have a significant impact on environment. The quantity of municipal solid waste produced in Tunisia was estimated to range from 0.5 to $1.5 \mathrm{~kg} / \mathrm{day} /$ person, characterised by a high percentage of fermentable organic matter (60 to $70 \%$ ). If we didn't select harmful materiel, at the beginning of composting, the quality of the mature compost can be affected. We may indicate an example the high percentage of heavy metals in the municipal solid composts. Some metals are mobile and can reach even the fruit or the groundwater ${ }^{[1]}$. The choice of another biodegradable material containing low quantities of toxic substances can be an interesting alternative for preserving the natural environment. For instances the important quantity of potential composted vegetable residues and market wastes of Tunis city estimated to more than 17 tons per day constitutes a favourable substrate for a biological treatment. Nevertheless more than $90 \%$ in volume of composted vegetable residues was composed by organic matter and was accompanied by relatively low water content, which requires its mixing with another waste. In another side Posidonia oceanica, the dominant sea grass species in the Mediterranean, where it covers $50000 \mathrm{~km}^{2}$ [2], is known to be a reef-building organism capable of long-term sediment retention. Posidonia oceanica is however experiencing a widespread decline throughout the Mediterranean sea, which may reduce sediment retention and increase beach erosion in the coastal zone ${ }^{[3]}$. For this fact, we will exploit for the preparation of Posidonia compost only dead plants of Posidonia collected near beaches. The sea plants Posidonia oceanica can be collected only neighbourly the hotel sectors and be transformed into compost. This sea plant is known by its high content in carbon, nitrogen and phosphorus. The desalination of this plant did not present a technical problem since Posidonia oceanica was a plant with a smooth surface, impermeable to salt existing in its natural environment and a simple rinsing eliminates the quasi totality of chlorides. Composting is a self-heating, aerobic, biodegradation process of organic waste materials. We can diversify the feed stockpile to reach mature compost with less heavy metal content. The present study investigates the exploitation of different wastes in goal to prepare stable compost. To establish a comparative study between the composting of different wastes; the prevailing of both physical-chemical conditions such as temperature, total organic matter, moisture, $\mathrm{C} / \mathrm{N}$ ratio, $\mathrm{pH}$ and microbial parameters such as pathogenic bacteria, $\mathrm{CO}_{2}$, deshydrogenase activity, present in the compost.

\section{MATERIALS AND METHODS}

Composting materials: Compost $\mathrm{C} 1$ was prepared with garden vegetable residues $(70 \%)$ mixed at the beginning with market wastes in order to correct the $\mathrm{C} / \mathrm{N}$ ratio. Compost $\mathrm{C} 2$ was prepared with mixture of vegetable residues $(70 \%)$ and the sea plant Posidonia which was washed for several times to eliminate all chlorides compounds. The substrate of the third pile $\mathrm{C} 3$ was a municipal solid waste collected from the area of Tunis City. Plastics and other undesired materials were removed and the substrate was added with $30 \%$ of bulking agents, i.e. wood. All types of wastes used were putted in piles of $\left(\mathrm{L} \times 1 \times \mathrm{H}=2 \times 1.5 \times 1.5 \mathrm{~m}^{3}\right)$. The compost piles were turned once the temperature dropped to $55^{\circ}-60^{\circ} \mathrm{C}$ and watered to $45-50 \%$ moisture content. The temperature was measured daily by a digital thermometer at the depth of 0.5 and $1 \mathrm{~m}$, in each pile.

Sampling procedure: Sampling was performed at the start of the composting process and repeated at the interval of 5 days by taking four samples. The last ones were taken immediately after mixing the pile. The heterogeneity of the urban residues constitutes a major difficulty to carry out a representative and reproducible sampling. A sample of $5 \mathrm{~kg}$ is taken starting from various points of the pile according to the method described by Gillet ${ }^{[4]}$. This same sample was used to take three reduced sub samples. The weight of each one was $1 \mathrm{~kg}$. The first sub sample was stored at $-40^{\circ} \mathrm{C}$ to provide a collection of sample; the second one was used for the physicochemical analyses and the third one served to the microbiological analyses. Experiments were started in April 2004.

Chemical analysis: During composting, the temperature was measured every two days at two depths in each pile $(0.5$ and $1 \mathrm{~m})$ with a temperature probe thermometer. The $\mathrm{pH}$ was determined in 1:10 $(\mathrm{w} / \mathrm{v})$ waters/ distilled water soluble extract, the humidity content was ascertained according to $\mathrm{Garcia}^{[5]}$ and organic carbon was determined according to the Anne method ${ }^{[4]}$. Total nitrogen was estimated based on 


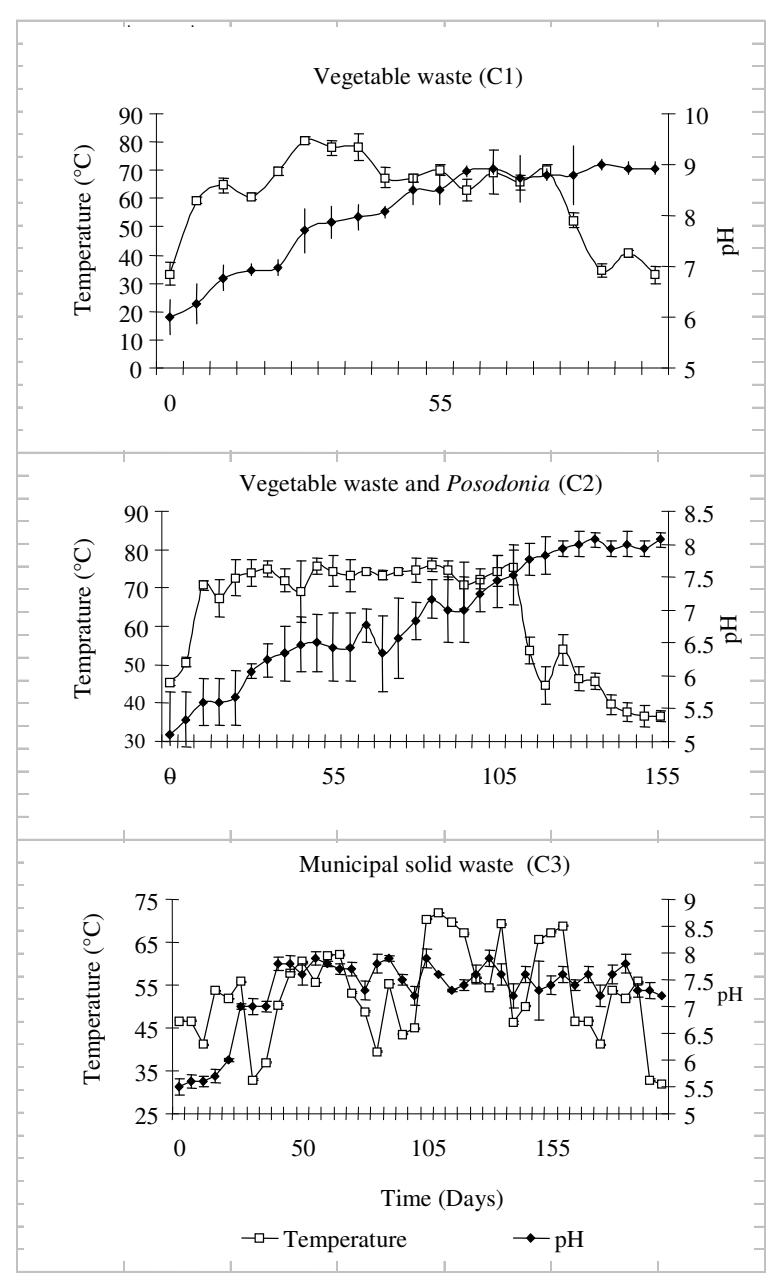

Fig. 1: Temperature and $\mathrm{pH}$ progress during the three cycles of composting Compost $\mathrm{C} 1$ was prepared with garden vegetable residues $(70 \%)$ mixed at the beginning with market wastes in order to correct the $\mathrm{C} / \mathrm{N}$ ratio. Compost $\mathrm{C} 2$ was prepared with mixture of vegetable residues $(70 \%)$ and sea plant Posidonia. This last one was washed for several times to remove all chlorides compounds. The substrate of the third pile C3 was municipal solid waste added with $30 \%$ of bulking agents.

the method of Bremmer ${ }^{[6]}$. Heavy metals content was determined following the method recommended by Rauret $^{[7]}$.

Microbial analysis: The enumeration of total microbial organisms (mesophilic and thermophilic) was done using the poured count agar method and incubation was made at 22 or $45^{\circ} \mathrm{C}$ during at least 5 days. Actinomyces count was realized by using antibiotic selection method $^{[8]}$. Concerning Bacillus enumeration, a weight of $10 \mathrm{~g}$ from each sample was diluted in a volume of $45 \mathrm{~mL}$ of sterile distilled water. Then, the aerobic Gram-positive purulent bacteria were isolated following the treatment of sporulation $\left(80^{\circ} \mathrm{C}\right.$ during 10 $\mathrm{mn})$. Purification of colonies was carried out by consecutive culture of the same clones for several times on the surface of the trypticase-soy-agar (TSA, oxoid). The purified colonies were stored in agar medium containing glycerol at $-20^{\circ} \mathrm{C}$. Bacillus isolates were confirmed by a microscopic observation after Gram staining, oxydase and catalase tests. The formation of endospore is tested in nutrient agar (NA, Oxoid) amended with $0.003 \%$ (weigh /vol) of manganese sulphate. Fungi enumeration was carried out on $10 \mathrm{~g}$ of each sample suspended in $40 \mathrm{~mL}$ of phosphate buffer (1.25 $\mathrm{g}$ of $\mathrm{KH}_{2} \mathrm{PO}_{4}, 2.80 \mathrm{~g}$ of $\mathrm{K}_{2} \mathrm{HPO}_{4}$ and $11 \mathrm{of}$ deionized water $\mathrm{pH} 7.1)$ and aliquots $(100 \mu \mathrm{l})$ from a serial dilution were plated on Potato dextrose agar (PDA)(250 $\mathrm{g}$ of autoclaved strained potatoes, $20 \mathrm{~g}$ of dextrose and $10 \mathrm{~g}$ of agar in 1liter of water). The inoculated plates were incubated for 3 days in darkness at $25^{\circ} \mathrm{C}+/-2^{\circ} \mathrm{C}$. The detection of Salmonella was determined as recommended by Standard methods of American Public Health Association ${ }^{[9]}$. The release of $\mathrm{CO}_{2}$ was measured according to Lasaridi $^{[10]}$. Deshydrogenase activity (DHA) was measured by spectrophotometer (Philips 8620 series) according to Tabatabai $^{[11]}$.

Evaluation of the compost toxicity using seed germination: The test was done at $27^{\circ} \mathrm{C}$ in darkness. Wheat seeds were sown (6 to 8 seeds) in Petri dishes containing paper soaked with the extract of compost or distilled water. After $48 \mathrm{~h}$ of incubation, the number of germinated seeds and the length of the roots were determined. An index of germination ( $\%$ of germination $\mathrm{x} \%$ of growth root) was determined. If the index lower than $50 \%$ as compared to the control test reveals an immaturity of the compost.

Statistical analysis: All experiments were repeated three times and analysed by the SPSS statistical program (SPSS for Windows, SPSS Inc.). The values presented are the average of three replicates and means were separated by the least significant difference according to the Student-Newman-Keuls Test. Pearson correlation determinations were also performed using SPSS statistical analysis. 


\section{RESULTS AND DISCUSSION}

pH, C/N ratio and temperature evolution: The thermophilic step was characterized by a temperature exceeding $60^{\circ} \mathrm{C}$, during 70 days at least for the three piles studied (Fig. 1). The temperature of the pile $\mathrm{C} 1$ reached $55^{\circ} \mathrm{C}$ only four days after the beginning of composting. The duration of thermophylic phase depends on the nature of the substrate; indeed the duration of the thermophyle phase is proportional to the duration of fermentation. The thermophylic period of municipal solid waste $\mathrm{C} 3$ last relatively a long time (150 days). Whereas, for the two other piles $\mathrm{C} 1$ and $\mathrm{C} 2$ the duration of thermophylic period was respectively 70 and 85 days. The shortest thermophilic phase of 70 days observed at the level of pile $\mathrm{C} 1$ was sufficient to remove the principal pathogenic bacteria. Watering was applied in order to recover the water loosed to have moisture ranging between 40 and $60 \%$. Moisture appeared to be a main influencing factor to microbial activity. Low moisture conditions can inhibit many beneficial microorganisms. However excess moisture increases the emission of anaerobic odours with production of certain toxic volatile substances such as methane ${ }^{[12,13]}$. Unlike the temperature, $\mathrm{pH}$ can be an indicator of maturity at the level of the three piles studied. The $\mathrm{pH}$ value reached at the end of the cycle of composting and at the level of the three piles was of about 8.5 (Fig. 1). The increase of $\mathrm{pH}$ values can be considered as an indicator of maturity. In addition, this alkalinity increase can act against some pathogenic fungi since a large number of fungi grow only under acid conditions ${ }^{[14]}$. The length of composting cycle depended on the nature of the waste used. The shortest cycle was observed at the level of pile $\mathrm{C} 1$ where the pile of composted vegetable residues lasted only 95 days. However, the addition of $30 \%$ of Posidonia to the pile delayed the operation of composting, which attained in this case 155 days. The longest fermentation period was observed for the pile of municipal solid waste (200 days); this result may due to the high heterogeneity of this substrate. The municipal solid waste cycle took twice as much time as that needed for the vegetable waste compost cycle, suggesting that a good choice of the substrate could lead to gain time.

The $\mathrm{C} / \mathrm{N}$ ratio represented one of the parameters to characterize the quality of the mixture of the feedstock. It ranged between 22 and 27 in the present experiment and decreased afterwards, according to the progress of the composting process (Fig. 2). We noted that microorganisms present in the compost of municipal solid waste, consumed part of nitrogen for 27 parts of carbon. The high values of $\mathrm{C} / \mathrm{N}$ ratio indicate that some

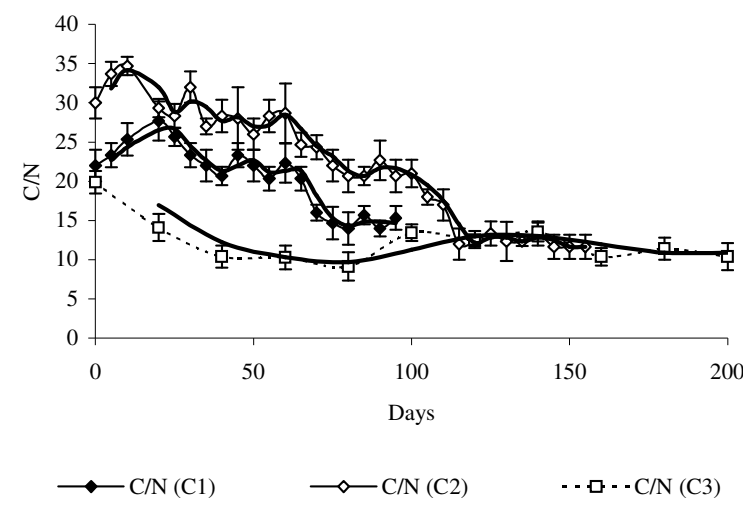

Fig. 2: $\mathrm{C} / \mathrm{N}$ ratio progress during the three composting processes studied

complex nitrogen substrates, such as keratin, were difficult to be used by the micro-flora. As a consequence, the microorganisms will need a longer period for its consumption. Haug ${ }^{[15]}$, found that an initial $\mathrm{C} / \mathrm{N}$ ratio varying from 30 to 35 seems to be an optimal condition for a fast composting of the municipal solid waste. This suggestion didn't exclude the fact that we also could have a fast biological breakdown even with a $\mathrm{C} / \mathrm{N}$ ratio lower than the limit recommended by Haug ${ }^{[15]}$. Indeed, the decrease of the $\mathrm{C} / \mathrm{N}$ ratio is explained by the transformation of carbon into carbon dioxide followed by a lower decrease in the concentration of organic acids ${ }^{[16]}$. At the end of the process, the values of $\mathrm{C} / \mathrm{N}$ varied between 10 and 15 (Fig. 2). According to Jedidi et al. ${ }^{[17]}$ this decrease corresponded to a stable form of the organic matter. So this $\mathrm{C} / \mathrm{N}$ ratio is regarded as a criterion of maturity of compost Hardy et al., ${ }^{[18]}$. Consequently, taken as condition of maturity, $\mathrm{C} / \mathrm{N}$ ratio showed that we obtain stable compost after only 200 days for municipal solid waste substrate. Hachicha and Ghoul ${ }^{[19]}$, showed that the maturity of the municipal solid waste compost was reached, only after 70 to 75 days according to a stabilisation of the $\mathrm{C} / \mathrm{N}$ value. This difference in duration can be attributed essentially to the nature and the composition of the waste in the pile. On the other hand, Hue and $\mathrm{Liu}^{[20]}$ established that this $\mathrm{C} / \mathrm{N}$ ratio was not a good indicator of compost stability. Currently, this $\mathrm{C} / \mathrm{N}$ ratio alone is not sufficient to determine the maturity of compost. It is therefore necessary to associate it with some others physico-chemical parameters such as the total organic matter and the tests of phyto-toxicity ${ }^{[21]}$. Certainly, low $\mathrm{C} / \mathrm{N}$ values didn't indicate the stability of the material. For example organic waste like manures, or activated sludge, presented sometimes the $\mathrm{C} / \mathrm{N}$ ratios lowers than 20 

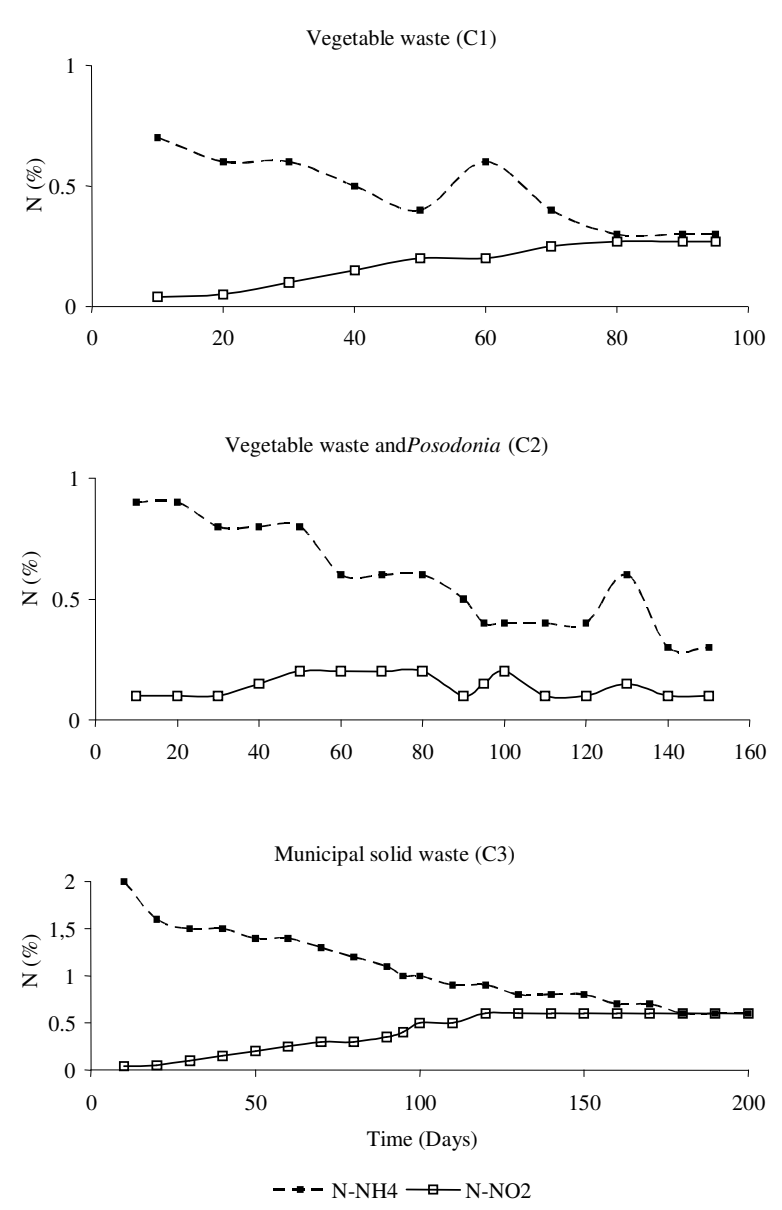

Fig. 3: Nitrogen content progress during the composting process

despite the instability of the product ${ }^{[15]}$. Moreover, Jedidi et al.$^{[22]}$ found that the incorporation of compost to soil with a high $\mathrm{C} / \mathrm{N}$ ratio caused a nitrogen immobilization and marked a real deficiency of nitrogen content for plant. The studies of Inbar et al. ${ }^{[23]}$, related to this $\mathrm{C} / \mathrm{N}$ ratio, showed that a compost with a weak $\mathrm{C} / \mathrm{N}$ ratio, could lead to a toxicity of the plants by $\mathrm{NH}_{3}$.

Nitrogen transformation during composting: During the operation of composting, the organic matter is transformed into mineral matter consumed by the bacteria. The percentage of $\mathrm{NH}_{4}-\mathrm{N}$ decreased during the composting process (Fig. 3). The nitrogen distribution $\left(\mathrm{NH}_{4}\right.$ and $\left.\mathrm{NO}_{2}\right)$ in the three piles during composting showed that at the end of composting, ammonia is converted to nitric acid $\left(\mathrm{NH}_{4}{ }^{+}+2 \mathrm{O}_{2} \rightarrow \mathrm{NO}_{3}\right.$ $\left.+2 \mathrm{H}^{+}+\mathrm{H}_{2} \mathrm{O}\right)$, (Schlgel ${ }^{[24]}$. The decrease of ammonia during composting depends on the rate of oxygenation.
Vegetable waste (C1)

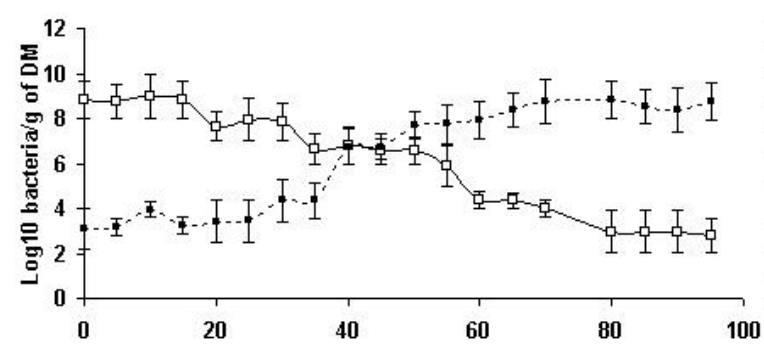

Vegetable waste and Posodonia (c2)
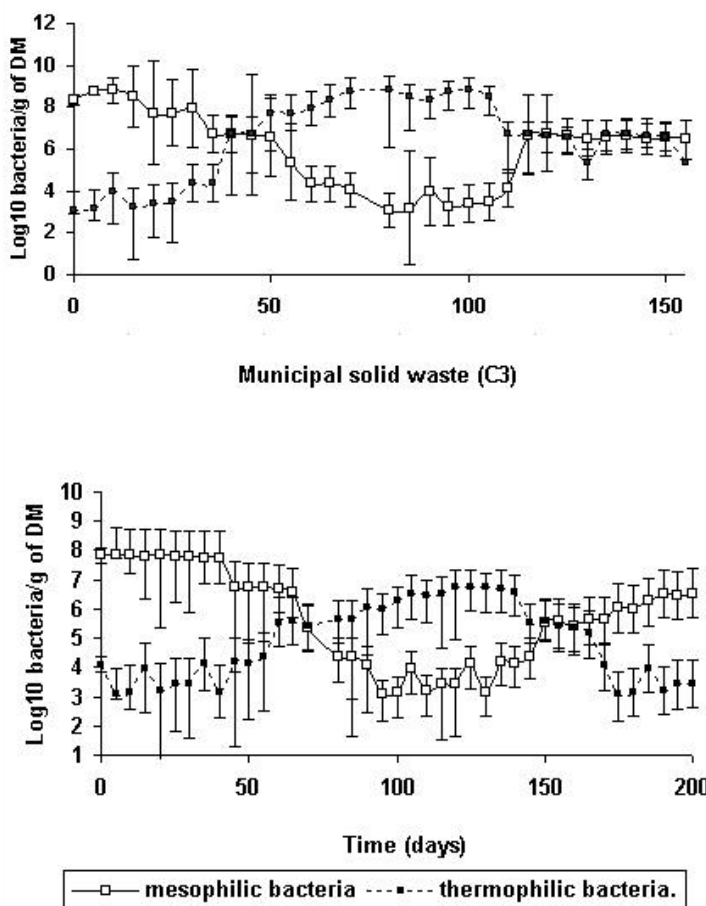

Fig. 4: Evolution of mesophilic and thermophilic bacteria during the three composting cycles

It can result that efficient quantity of $\mathrm{O}_{2}$ can decrease emission of ammonia during the process and accelerate the rate of mineralization ${ }^{[25]}$. At the end of composting, all piles $\mathrm{NH}_{4}-\mathrm{N}$ content didn't exceed the maximum value for a mature compost $\left(400 \mathrm{mgKg}^{-1}\right)$, as recommended by Zucconi and Bertoldi ${ }^{[26]}$. The amount of nitrogen recorded was important in the pile of municipal solid waste $\mathrm{C} 3\left(2 \%\right.$ of $\mathrm{NH}_{4}$ at the beginning of composting); these values are lower at the level of the composts $\mathrm{C} 2(0.9 \%)$ and $\mathrm{C} 1(0.7 \%)$. These results suggest that the municipal solid waste lead to the 
production of a compost more rich in nitrogen and can be a better fertilizer as compared to the two other studied composts used. The monitoring of this mineralization during a cycle of composting can be used as criterion of the compost maturity evaluation.

Microbial dynamics: A large variety of mesophilic and thermophilic microorganisms was isolated from compost sampled at different periods during the composting process. These microorganisms can grow at temperatures varying between 10 and $70^{\circ} \mathrm{C}$. Under aerobic conditions, temperature is a major factor determining microbiologic variety and the intensity of metabolic activities ${ }^{[27]}$. According to (Fig. 4), during the mesophilic phase there is a dominance of the mesophilic bacteria with a concentration of $10^{4}$ microorganisms $\mathrm{g}^{-1}$ of dry matter. It is the natural flora that colonizes the first substrate degrades preferentially the fresh organic-matter. At this stage, we have the degradation of the easy degradable materials such as sugars, proteins, etc. This idea was supported by the level of deshydrogenase activity, which was in the order of $4.8 \mathrm{mg} \mathrm{TPF} \mathrm{g}^{-1}$ of dry matter for the municipal solid waste; this value can be the result of a high oxidation rate of the organic matter. This intense activity led to the increase of $\mathrm{CO}_{2}$ release and of temperature $^{[28]}$. During this thermophilic phase, the number of mesophilic bacteria decreased and fluctuated between $10^{3}$ and $10^{4}$ microorganisms $\mathrm{g}^{-1}$ of dry matter. These mesophilic bacteria were partially killed as compared to the thermophilic, which number increased appreciably and reached more than $10^{7}$ microorganisms $\mathrm{g}^{-1}$ of dry matter during the thermophilic phase. Mustin $^{[29]}$, noticed that the microorganisms of the compost, at any moment, create the conditions of their own destruction, which are to be optimal for the following microbial populations engaged in composting. During the cooling phase, the number of thermophilic bacteria decreased appreciably to $10^{5}$ and $10^{4}$ microorganisms $\mathrm{g}^{-1}$ dry matter for $\mathrm{C} 2$ and $\mathrm{C} 3$, respectively, but it has conversely increasd to more than $\mathrm{CO}_{2}$ release was constant during the thermophilic step. Progress of $\mathrm{CO}_{2}$ release in the different piles $\mathrm{C} 1, \mathrm{C} 2$ and $\mathrm{C} 3$ (Fig. 5) showed the same tendency that can be divided in two phases. The first one appeared at the thermophilic period with high release and the second appeared at the maturity period with low release. For example composted vegetable residues emitted, after 70 days of composting approximately $6000 \mathrm{mg} \mathrm{C}-\mathrm{CO}_{2}$ dry $\mathrm{kg}^{-1}$, this value deceased at the end of composting to $2300 \mathrm{mg} \mathrm{C}-\mathrm{CO}_{2}$ dry kg${ }^{-1}$. A stabilisation of the $\mathrm{CO}_{2}$ release was observed during maturity step. These results suggest that $\mathrm{CO}_{2}$ release can be a determinant

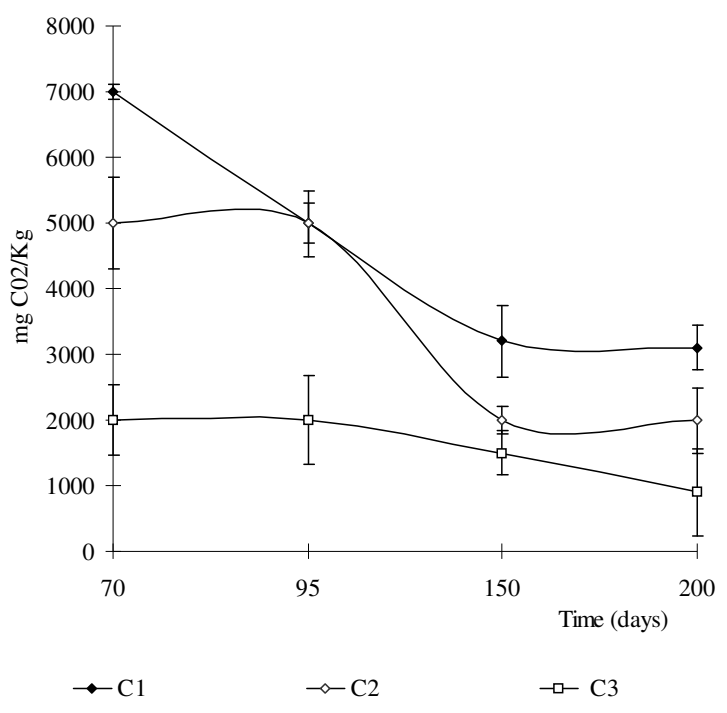

Fig. 5: Progress of $\mathrm{CO}_{2}$ release during the three composting process studied $10^{8}$ in the case of the composted vegetable residues $\mathrm{C} 1$. This number didn't decrease either at the end of the composting process.

factor that can indicates compost maturity. The municipal solid waste pile $\mathrm{C} 3$ emitted during the thermophilic phase approximately $2000 \mathrm{~g} \mathrm{C}-\mathrm{CO}_{2} \mathrm{~kg}$ DM. This may be related to the structure of the municipal solid waste material which is different from that of the vegetables residues. The last material has a non-compact texture that enables the circulation of air and can let volatile compounds such as $\mathrm{CO}_{2}$ and their absorption by alkaline solutions. Generally, the trends in respiration rates of the compost at different ages correspond to changes of the chemical and physical parameters observed during composting ${ }^{[30]}$. These results suggest that the $\mathrm{CO}_{2}$ measurement can be an indicative parameter of the maturity of the compost. On the other side, it would be interesting to choose a substrate with less $\mathrm{CO}_{2}$ production in order to preserve the environment. For utilization in container media, a higher stability level $\left(0.5 \mathrm{mg} \mathrm{CO} 2-\mathrm{C} \mathrm{g}^{-1} \mathrm{DM}\right)$ may be required. Presently, composts are typically used on the basis of past experiences with specific products from given suppliers instead of their use on the basis of standard physical, chemical and/or biological properties of the products that define quality.

Generally the compost enzyme activities are very considered to be sensitive to different experimental conditions and feed stock sources. Therefore, enzyme activities can be considered as effective indicators for stress or management practices. It is also obvious that 


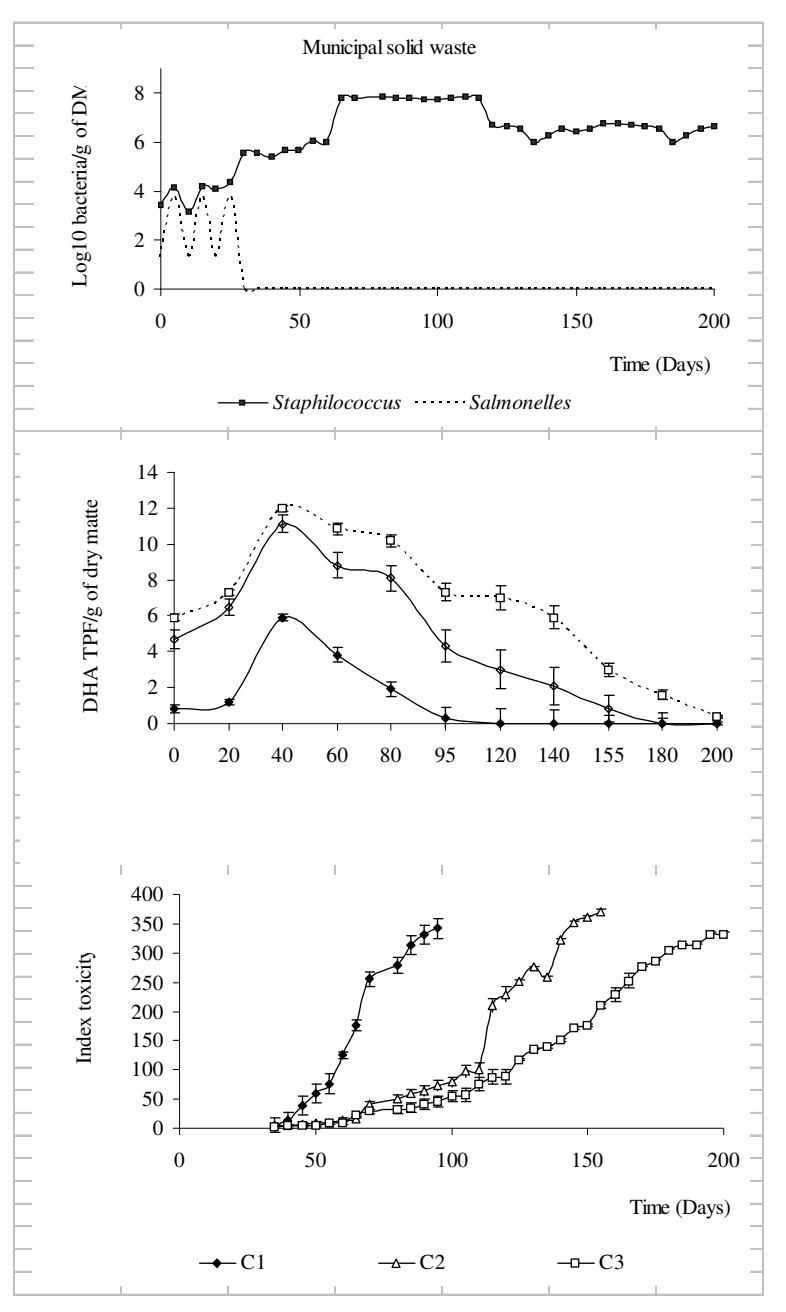

Fig. 6: Deshydrogenasease activity, pathogenic bacteria and toxicity index progress during the three composting cycles

the relationship between an individual biochemical property and the total microbial activity is not always obvious, especially in the case of complex systems like compost, where the microorganisms and processes involved in the degradation of the organic compounds are highly diverse. Nevertheless, deshydrogenase activity (DHA) has been used as an indicator of the microbiological activity in soils ${ }^{[5]}$, The (DHA) measure during composting operation on the three different feedstock can indicate compost stability. The mesophilic phase was characterized by a weak The compost $\mathrm{C} 1$ was prepared from composted vegetable residues $(70 \%)$ mixed with respectively $(10 \%)$ of mature compost of composted vegetable residues. The compost $\mathrm{C} 2$ was prepared from a mixture of composted vegetable residues (70\%) and Posidonia oceanica. The fourth pile $\mathrm{C} 3$ was composed of municipal waste collected of the area of Tunis. deshydrogenase activity (Fig. 6). At the beginning of the cycle, the rate of DHA at the level of the three piles studied $\mathrm{C} 1, \mathrm{C} 2$ and $\mathrm{C} 3$ was in the order of $0.8 ; 4.5$ and $6 \mathrm{TPF} / \mathrm{TPF} / \mathrm{g}$ of DM, respectively. During the thermophilic phase, a light increase of the enzyme activity observed and reached at the level of the three piles $\mathrm{C} 1, \mathrm{C} 2$ and $\mathrm{C} 3$ the values 5.9; 6.2 and 12 $\mathrm{TPF} / \mathrm{TPF} / \mathrm{g}$ of $\mathrm{DM}$ respectively. At the maturation stage, there is a net decrease of the DHA neighbouring $0.3,0.8$ and 0.4 , respectively at the level of the three piles. This result indicates that the measure of DHA activity was predictive of the compost maturity. The DHA activity varied almost positively with the amount of soil organic matter. Indeed, the lower $\mathrm{pH}$ compost values associated to a higher $\mathrm{C} / \mathrm{N}$ ratio, lead to a slow decomposition rate and consequently lead to less DHA activity than during the thermophilic phase.

Other authors also attributed the increase of the microbial activity to the high compost moisture. Generally, young composts exhibited a greater enzymes activity than the oldest ones. In the amended soil, the composts did not increase enzyme activity in an additive way. Deshydrogenase, the only strictly endocellular enzyme, was the only one for which the activity in the amended soil increased significantly in proportion to the addition of the compost. During the incubations, $\mathrm{C}$ mineralization and DHA activity were significantly correlated, indicating that deshydrogenase activity was a reliable indicator of global microbial activity $^{[31]}$.

Pathogenic bacteria during composting cycle: One of the purposes of composting was to eliminate the pathogenic microorganisms and to avoid a later recontamination of waste ${ }^{[32]}$. Indeed, some authors have used tests of recontamination by inoculating Salmonella or $E$. coli in compost pile to find the optimal conditions of pasteurisation ${ }^{[33]}$. They noticed that final compost humidity must be lower than $20 \%$ and the ratio $\mathrm{C} / \mathrm{N}$ ratio must be lower than 15 . Composting must suppressifs all pathogenic bacteria. In our study salmonella was absent at the level of the two piles $\mathrm{C} 1$ and $\mathrm{C} 2$, but this bacteria appeared in $\mathrm{C} 3$ pile only at the beginning of composting (Fig. 6). These bacteria were destroyed when the temperature reached $55^{\circ} \mathrm{C}^{[34]}$. Salmonella come essentially from the detriments of food and of meats. Salmonella species are regarded as the problem of the hygienic quality of the compost. This is probably related to the fact that these bacteria are ubiquist and of rapid growth. In the compost, they 
The compost C1 was prepared from composted vegetable residues $(70 \%)$ mixed with respectively $(10 \%)$ of mature compost of composted vegetable residues. The compost $\mathrm{C} 2$ was prepared from a mixture of composted vegetable residues (70\%) and Posidonia oceanica. The fourth pile C3 was composed of municipal waste collected of the area of Tunis are represented primarily by Salmonella sp., S. munchen and $S$. corvalis ${ }^{[35]}$. Concerning staphylococci, they were absent at the level of the two piles $\mathrm{C} 1$ and $\mathrm{C} 2$. The number of these bacteria was more important at the level of $\mathrm{C} 3$, where they have fluctuated between $10^{3}$ and $10^{5}$ bacteria $\mathrm{g}^{-1}$ of dry matter. Their presence at the end of the cycle can be disturbing; however we noted the absence of Staphylococcus aureus. In the domestic municipal solid compost staphylococcus xylosus was the main species observed. This bacterium is natural colonizer of soils.

Quality of composts: At the end of the composting process, the three finished products showed the average characteristics regrouped in Table 1. Sstatistical studies showed that there were no significant differences between the main components of the three mature composts obtained. Only the municipal solid waste compost C3 presented a salinity value $\left(6.8 \mathrm{~g} \mathrm{Kg}^{-1}\right.$ of $\mathrm{DM})$, higher than those registered at the level of the two other piles studied $\left(2.6 \mathrm{~g} \mathrm{Kg}^{-1}\right.$ of DM for $\mathrm{C} 1 ; 4 \mathrm{~g} \mathrm{Kg}^{-1}$ of DM for C2). We also noted that the compost $\mathrm{C} 2$ was rich in $\mathrm{P}_{2} \mathrm{O}_{5}(2.17 \% / \mathrm{g}$ of $\mathrm{DM})$ and $\mathrm{MgO}$ (2.62\% of $\mathrm{DM})$, as compared to the two other piles studied $(\mathrm{C} 1$ : $0.73 \%$ of DM; and C3: $0.8 \%$ of DM). Bacteriological analyses of the finished products deriving from the three organic matters showed a significant difference between the numbers of the various microbial groups

analyzed (Table 2). All finished products obtained didn't contain Salmonella (Table 2). Concerning the analysis of heavy metals, high content were found at the level of the three piles studied. Nevertheless, these quantities of heavy metal didn't exceed the doses recommended by the USEPA standards ${ }^{[36]}$ (Table 3). However, the application of such product to soil during successive years can lead to the accumulation of some metals in soil, such as chrome is known by its immobilization properties in soil. Heavy metals in compost pose a problem both at the environmental and agricultural levels. The heterogeneity of municipal solid waste and the inability to select the no degradable material in the feedstock may affect the quality of the mature compost ${ }^{[37]}$. The presence of heavy metals in the compost can be the result of the presence of different previous sources such as tubes, capsules, etc. Copper can result from fungicides. On the other hand, the cadmium and $\mathrm{Pb}$ can result from batteries and fuel respectively.

Table 1: Physical and chemical characterisation of the different mature compost obtained from three organic matters studied Finished compost

\begin{tabular}{|c|c|c|c|}
\hline & \\
\hline & $\mathrm{C} 1$ & $\mathrm{C} 2$ & $\mathrm{C} 3$ \\
\hline Humidity (\%) & 34 & 35 & 25 \\
\hline $\mathrm{PH}$ & 7.8 & 7.5 & 7.5 \\
\hline Salinity (g/Kg dry matter) & 2.6 & 4 & 6.8 \\
\hline Organic matter (\%/g of dry matter)) & 31 & 3.5 & 26.5 \\
\hline Tot N (\%/g of dry matter)) & 0.89 & 1.3 & 1.04 \\
\hline $\mathrm{K}_{2} \mathrm{O}(\% / \mathrm{g}$ of dry matter $\left.)\right)$ & 0.74 & 0.9 & 0.62 \\
\hline $\mathrm{CaO}(\% / \mathrm{g}$ of dry matter $))$ & 3 & 5.2 & 17.7 \\
\hline $\mathrm{C} / \mathrm{N}$ & 22 & 15 & 17 \\
\hline $\mathrm{Na} 2 \mathrm{O}(\mathrm{g} / \mathrm{Kg}$ dry matter $)$ & 12 & 7 & 4 \\
\hline P2O5 (\%/g of dry matter)) & 0.53 & 2.17 & 0.6 \\
\hline $\mathrm{MgO}(\% / \mathrm{g}$ of dry matter) & 0.73 & 2.62 & 0.8 \\
\hline
\end{tabular}

Table 2: Microbiological parameters evolution during a cycle composting at the level of three different fermentescible matrix

\begin{tabular}{|c|c|c|c|c|c|c|}
\hline $\begin{array}{l}\text { Finished } \\
\text { Compost }\end{array}$ & $\begin{array}{l}\text { Mesophilic } \\
\text { bacteria }\end{array}$ & $\begin{array}{l}\text { Thermophilic } \\
\text { bacteria }\end{array}$ & Coliform & Actinomyces & Fungi & Salmonelle \\
\hline$\overline{\mathrm{C} 1}$ & $2710^{5}$ (a) & $2210^{6}(a)$ & 27 (a) & $1710^{5}(\mathrm{a})$ & $1310^{4}(\mathrm{a})$ & 0 (a) \\
\hline $\mathrm{C} 2$ & $2710^{5}$ (a) & $3810^{5}(\mathrm{c})$ & 28 (b) & $1410^{5}(\mathrm{c})$ & $8510^{4}(\mathrm{c})$ & 0 (a) \\
\hline $\mathrm{C} 3$ & $3510^{5}(\mathrm{~b})$ & $3210^{5}$ (d) & 15 (c) & $4010^{5}(\mathrm{~d})$ & $1210^{5}(\mathrm{~b})$ & 0 (a) \\
\hline
\end{tabular}

(*) Means followed by the same letter are not significantly different at $\mathrm{p}=0.5$

Table 3: Determination of heavy metals concentrations at the level of the three types of composts tested as compared to standard norms

\begin{tabular}{|c|c|c|c|c|c|c|}
\hline \multirow{2}{*}{$\begin{array}{l}\text { Finished } \\
\text { Compost }\end{array}$} & \multicolumn{2}{|c|}{ Metal $\left(\mathrm{g} \mathrm{kg}^{-1} \mathrm{MS}\right)$} & \multirow[b]{2}{*}{$\mathrm{Cd}$} & \multirow[b]{2}{*}{$\mathrm{Zn}$} & \multirow[b]{2}{*}{$\mathrm{Ni}$} & \multirow[b]{2}{*}{$\mathrm{Pb}$} \\
\hline & $\mathrm{Cr}$ & $\mathrm{Cu}$ & & & & \\
\hline $\mathrm{C} 1$ & $11.41 \pm 0.07$ (a) & $30.3 \pm 0.16$ (a) & $1.9 \pm 0.1(\mathrm{a})$ & $175.74 \pm 0.06$ (a) & $50.04 \pm 0.01(\mathrm{a})$ & $120.27 \pm 0.20$ (a) \\
\hline $\mathrm{C} 2$ & $18.36 \pm 0.07$ (b) & $54.49 \pm 0.10(\mathrm{~b})$ & $1.76 \pm 0.05(b)$ & $300.26 \pm 0.16$ (b) & $98.16 \pm 0.17$ (b) & $245.25 \pm 0.15$ (b) \\
\hline $\mathrm{C} 3$ & $22.42 \pm 0.03(\mathrm{c})$ & $88.84 \pm 0.06$ (c) & $2.01 \pm 0.01(\mathrm{c})$ & $400.12 \pm 0.13(\mathrm{c})$ & $99.70 \pm 0.57$ (c) & $306.66 \pm 0.01$ (c) \\
\hline EUN - & 1000 & 20 & 2500 & 300 & 750 & \\
\hline USEPA & - & 1500 & 39 & 2800 & 420 & 300 \\
\hline
\end{tabular}

USEPA Standards for the use or disposal of sewage sludge. Fed regist. 58: 9248-9415.

(*) Means followed by the same letter are not significantly different at $\mathrm{p}=0.5$. 
$\mathrm{Pb}$ was present at high amounts essentially in vegetable compost. The origin of this metal in such substrate can be attributed to traffic car in the nearly streets. So, the risk of heavy metals reside essentially in their concentration during the process because there is a loss of the organic matter and an absence of biodegradability of heavy metals and their harmful effect when added to soil.

The evaluation of the compost toxicity revealed that the finished products derived from the different feedstock didn't present toxicity since the index of germination was higher than $50 \%$ compared to the control. The index of toxicity is a major parameter in the determination of the maturity of the compost. Fig. 6 shows that maturity is reached when the index value is close to the half of the value of the control test. The index for the control has a value equal to 396 . Consequently the start of maturity is indicated when the index value attain 198. This value is reached on the level of the pile $\mathrm{C} 1$ after 70 days; however the addition of Posidonia delayed the maturity by 50 days. With regard to the third municipal solid substrate, the maturity started only after 155 days of the beginning of the cycle of composting.

\section{CONCLUSION}

Compost from different feedstock sources provided stable compost with a $\mathrm{C} / \mathrm{N}$ ratio of around 15. All parameters used are important for the characterization of compost maturity. However, to preserve the environment, it would be useful to choose a substrate which leads to less pollution by $\mathrm{CO}_{2}$ and with a short time of composting. Taking account of these two parameters, the composted vegetable residues enriched with Posidonia can be an interesting substrate in compost production. In the basis of the obtained results, it can be concluded that the composting operation is affected by the nature of feed stockpiles. Monitoring of various parameters such as temperature, $\mathrm{pH}, \mathrm{NH}_{4}, \mathrm{NO}_{3}$ and $\mathrm{CO}_{2}$ release during the composting process can be critical to characterize compost maturity. Indeed and in the same context, soluble-C, soluble-N, $\mathrm{NH}_{4}{ }^{+}, \mathrm{NO}_{2}{ }^{-}$and their ratios give a good profile of the compost evolution. The starting organic matters affect the quality of finished compost. However, heavy metals content may constitute an ecological and agricultural problem, since they can be accumulated in soil and exceed the limits indicated by norms. Our investigations revealed variation in the size of the different microbial populations (bacteria, fungi and Actinomyces). The three organic substrates studied led to a stable compost exempt of pathogenic bacteria, except at the level of the municipal solid compost C3 where saprophyte Staphylococcus was found at high concentrations (S. xylosus). These same biological and biochemical properties vary widely in accordance with the type and the range of biodegradable materials and process characteristics. In addition this report describes the importance of such data and information for producers and grower and recommends the use of Posodonia as an alternative to domestic compost.

\section{ACKNOWLEDGEMENTS}

This study was supported by the Tunisian Ministry of Research and Technology. The authors are grateful to all technichal staff in Recycling and Treatment Laboratory, especially for, Mabrouki Zakia and Issaoui Khaled.

\section{REFERENCES}

1. Jedidi, N., K. Hamdi, F. Ayari, A. Hassen and A. M'hiri, 2003. Magnetic susceptibility variation of MSW compost-amended soils: In-situ method for monitoring heavy metal contamination. Waste Manag. and Res., 21:155-160.

2. Bethoux, J.P. and G. Copin-Monte gut, 1986. Biological fixation of atmospheric nitrogen in the Mediterranean Sea. Limnology and Oceanography, 31: 1353-1358.

3. Marba, N., C.M. Duarte, J. Cebrian, M.E. Gallegos, B. Olesen and K. Sand Jensen, 1996. Growth and population dynamics of Posidonia oceanica in the Spanish Mediterranean coast: Elucidating sea grass decline. Marine Ecology Progress, 137: 207-213.

4. Gillet, R., 1986.Traité de gestion des déchets solides and son application aux pays en voie de développement. les traitements industriels des ordures ménagères et des déchets assimilés. Organisation et gestion d'un service, pp: 1986-538.

5. Garcia, A.J., M.B. Esteban, M.C. Marquez and P. Ramos, 2005. Biodegradable municipal solid waste: characterization and potential use as animal feedstuffs. Waste Manag., 25: 780-786.

6. Bremner, J.M. and C.S. Mulvaney, 1982. Total Nitrogen. In: C.A. Black et al., Eds. Methods of Soil Analysis. Part 2. Chemical and Microbiological Properties. Am. Soci. Agronomy. Madison, WI, pp: 595-622.

7. Rauret, G., 1998. Extraction procedures for the determination of heavy metals in contaminated soil and sediment. Talanta, 46: 449-455.

8. Athalye, M., J. Lacey and M. Goodfellow, 1981. Selective isolation and enumeration of Actinomycetes using rifampicin. J. Appl. Bacteriol, 51: 289-297.

9. American Public Health Association. 1998. Standard methods for the examination of water and wastewater, 20th Edn. Am. Pub. Health Associ., Washington, D.C. 
10. Lasaridi, K.E. and EI. Stentiford, 1998. A simple respirometric technique for assessing compost stability. Water Res., 32: 3717-3723.

11. Tabatabai, M.A., 1994. Soil Enzymes. Methods of Soil Analysis. Part 2. Microbio. and Biochem. properties. SSSA. Book series $n^{\circ} 5$.

12. Richard, T.1. and L.P. Walker, 1999. Oxygen and temperature Kinetics of Aerobic Solid state Biodegradation. In ORBIT 99: Organic Recovery and Biological Treatment. Proceedings of the International Conference ORBIT 99 one Biological Treatment of Waste and the Environment.

Bidlingmaier, De. Bertoldi, L.F. Diaz and E.K. Papadimitriou (eds.), Rhombos-verl., Berlin, pp: 85-91.

13. Richard, H.T., H.V. Bert Hamelers, A. Veeeken and T. Silva, 2002. Moisture relationships in composting processes. Compost Sciences and use., pp: 286-302. Epstein, E., 1997. The sciences of composting. Technomic Publishing Co, Inc. Basel, Switzerland.

14. Saidi, N., A. Hassen, M. Chérif, M.R. Hajlaoui, N. Jedidi, O. Bouzaeine, A. Ghrabi, A. Boudabous, E.K. Abdel kéfi and M. Fumio, 2006. Effet d'un compost d'ordure ménagère sur la fusariose du blé (Fusarium culmorum).Vect. Env. pp: 47-54.

15. Haug, R.T., 1993. The Practical Handbook of Compost Engineering. Lewis Publishers, Boca Raton, Fl., pp: 71-77.

16. Chefetz, B., P.G. Hatcher, Y. Hadar and Y. Chen, 1998. Characterization of Dissolved Organic Matter Extracted from Composted Municipal Solid Waste. Soil Sci. Soc. Am. J., 62: 326-332.

17. Jedidi, N., O. Van Cleemput, A. Mhiri, R. Hachicha and A. Hassen, 1991.Utilisation du Carbone Marqué ${ }^{14} \mathrm{C}$ pour l'Etude de la Minéralisation de Trois types de compost des ordures ménagères. Revue de l'INAT, 6: 63-79.

18. Hardy, V., F. Klaus and T. Thomas, 1993. Quality Physical Characteristics Nutriment Content Heavy Metals and Organic Chemicals in Biogenic Waste Compost. Compost Sci. Util. 1:69-87.

19. Hachicha, R. and M. Ghoul, 1991. Compostage des déchets Urbains: contribution à l'étude des Paramètres Physico-chimiques et Micro biologiques. Revue de l'INAT. 6: 5-17.

20. Hue, N.V. and J. Liu, 1995. Predicting Compost Stability. Compost Sci. Util., 3: 8-15.

21. Goyal, S., S.K. Dhull, K.K. Kapoor, 2005. Chemical and biological changes during composting of different organic wastes and assessment of compost maturity. Bioresour Technol., 96: 1584-1591.

22. Jedidi, N., A. Hassen, O. Van Cleemput and A. M'hiri, 2001. Caractérisation du Compost et des Résidus Urbains Utilisés comme Amendements Organiques dans le Sol. Revue de 1'INAT.,15 : 1-16.

23. Inbar, Y., Y. Chen and Y. Hadar, 1990. Humic substances formed during the composting of organic matter. Soil. Sci. Soc. Am. J., 54:1316-1323.

24. Schlgel, HG. General Microbiology, 1993. 7th Edn. Cambridge University Press, New York Waginigen Agricultural University, Wagenigen, the Netherlands.
25. Veeken, A.H., M.V. Dewilde and H.V.M. Halmers, 1999. Reduction of ammonia emissions during composting by uncoupling of oxygen demand and heat removal, Proceedings Int. conference Orbit 99, Weimar, Germany.

26. Zucconi, F. and M. de Bertoldi, 1987.Compost specification for the production and characterisation of compost from municipal solid waste. In: de Bertoldi M., M. Ferranti, P. L'hermite, F. Zucconi, (Ed), Compost Production Quality and Use. Elsevier, London, pp: 3050.

27. Amner, W., A.J. Mc Carthy and C. Edwards, 1988. Quantitative Assessment of Factors Affecting the Recovery of Indigenous and the Release of Thermophilic Bacteria from Compost. Appl. Environ. Microbiol, 54: 3107-3112.

28. Hellmann, B., L Zelles, A. Palojarvi and Q. Bai, 1997. Emission of Climate-Relevant Trace Gases and Succession of Microbial Communities during OpenWindrow Composting. Appl. Environ. Microbiol., 63:1011-1018.

29. Mustin, M., 1987. Le Compost gestion de la matière organique. Editions François Dubusc. Paris, pp: 953.

30. Saviozzi, A., R. Cardelli, R. Levi-Minzi and R. Riffaldi, 2004. Evolution of biochemical parameters during composting of urban wastes. Compost Science and Utilization, $\quad 12: 153-160$.

31. Wittling, S.C., S. Houot and E. Barriuso, 1995. Soil enzymatic response to addition of municipal solid-waste compost, Biol-fertil-soils, 20: 226-236.

32. Venglovsky, J., N. Sasakova, M. Vargova, Z. Pacajova, I. Placha, M. Petrovsky and D. Harichova, 2005. Evolution of temperature and chemical parameters during composting of pig slurry solid fraction amended with natural zeolite. Bioresour., Technol., 96:181-189.

33. Soares, H.M., B. Cardenas, D. Weir and M.S. Switzenbaum, 1995. Evaluating pathogen regrowth in bio solids compost. Bio cycle, pp: 70-76.

34. Martens, J., 2005. Indicator methods to evaluate the hygienic performance of industrial scale Operating Bio. waste Composting Plant. Waste Manag. and Res., 25: 435-444.

35. Hassen, A., K. Belguith, N. Jedidi, A. Cherif, M. Cherif and Boudabbous, 2001. Microbial Characterization during Composting of Municipal Solid Waste. Bio. resource. Techno., 80:185-192.

36. USEPA, 1993. Standards for the use or disposal of sewage sludge. Fed Regist., 58: 9248-9415.

37. Morvan, B., 1995. Carré J. Oligo-éléments et micro polluants dans les composts. Tech. Science Municipales. 2: $138-140$. 